\title{
Lowering of Phytic Acid Content by Enhancement of Phytase And Acid Phosphatase Activities during Sunflower Germination
}

\author{
Juliana da Silva Agostini, Rosicler Balduíno Nogueira and Elza Iouko Ida* \\ Departamento de Ciência e Tecnologia de Alimentos; Centro de Ciências Agrárias; Universidade Estadual de \\ Londrina; C. P.: 6001; 86051-970; Londrina - PR - Brasil
}

\begin{abstract}
The objective of this work was to investigate the germination of hybrid sunflowers BRS191 and C11 as a means of lowering phytic acid (PA) content by enhancing the activity of endogenous phytase and acid phosphatase. The concentration of PA in hybrid sunflower achenes varied from 2.16 to $2.83 \mathrm{~g} / 100 \mathrm{~g}$ of sample ( $p<0.05$ ). The phytase and acid phosphatase activities of sunflowers BRS191 and C11 were the highest on the $4^{\text {th }}$ and $5^{\text {th }}$ days of germination, respectively, with the release of the phosphorus. These results indicated that hybrid sunflower PA reduced and enhance phytase activity at distinct germination periods, which could open up the possibility of applying these enzymes in the control of PA content in cereals, thus improving their nutritional value.
\end{abstract}

Key words: germination, sunflower hybrids, phytic acid, phytase, acid phosphatase

\section{INTRODUCTION}

Sunflower production has increased worldwide and Brazil presents excellent production prospects. Sunflower grain has been used for extracting high quality cooking oil and its residue is normally used as a meal in animal feeds and alternatively as an isolated protein to enrich the baking flour and meat products for human consumption (Reyes et al., 1985; Rossi, 1997). However, as other grains, sunflower contains from 0.4 to $6.4 \%$ phytic acid (PA) (Harland and Oberleas, 1987; Egli, et al., 2002). About $70-80 \%$ of the total phosphorus present in grains derives from phytates, and PA is the main form of phosphorus storage (Reddy et al., 1982). Due to its chemical structure, PA chelates certain essential minerals, which decreases its bioavailability. In contrast, monogastric animals such as birds, pigs, and humans eat various types of cereals that contain phosphate in the form of phosphorus-phytate, which is unavailable for intestinal phytase activity (Wodzinsk and Ullah, 1996). Some in vitro reports state that phytates can complex with proteins, making them insoluble and, thus, biologically unavailable under normal human physiological conditions (Cheryan, 1980). Furthermore, protein-phytate complexes are less sensitive to enzymatic activity in relation to free proteins (Cheryan, 1980). PA has also been described as a potent natural antioxidant in food (Graf and Eaton, 1990) and to have anticarcinogenic effects (Zhou and Erdman, 1995; Oatway et al., 2001; Minihane and Rimbach, 2002). Other beneficial antioxidizing effects have

*Author for correspondence: elida@uel.br 
been observed as an exogenous additive in fresh broiler breast meat (Soares et al., 2003) and as an endogenous ingredient in swine diet (Harbach et al., 2007). All these reports show the controversial biological role of PA. PA enzymatic hydrolysis has been put forward as an alternative to improve the nutritional value of grain food (Sandberg et al., 1996; Egli et al., 2002) and to decrease the amount of phosphorus in excreta, which is considered to cause pollution in intensive farming (Simons and Verteegh, 1990).

Agostini and Ida (2006a) investigated the germination of hybrid sunflower M734 by response surface methodology and observed minimal phytate and acid phosphatase activity on the $6^{\text {th }}$ day of germination at $30^{\circ} \mathrm{C}$. The best conditions for phytase activity were the $4^{\text {th }}$ day of germination at the same temperature. Other studies by different techniques suggest a decrease or control in PA content (Reddy et al., 1982; Coelho et al., 2008). Phytases or mio-inositolhexaphosphate phosphohydrases (EC 3.1.3.26) or 6-phytases are phytate-specific phosphatases that hydrolyze PA or mio-inositol hexaphosphate to inositols and phosphates (Reddy et al., 1982). Some reports state that the physiological function of phytases in grains is related to the release of inorganic phosphorus (Pi) from phytate, being mostly incorporated in nucleic acids (Houde et al., 1990; Wodzinsk and Ullah, 1996; Lopez et al., 2002). These works pointed out that phytases are were responsible for the enzymatic degradation of phytates, and their activity increased during seed germination, and that free Pi might be connected to cell energy production. Phytases also play a practical role as an additive and the reduction of PA residues in the animal feed and the improvement of food consumption as a consequence of their nutritive value (Greiner et al., 1998). Hybrid sunflower M734 phytase is heatstable at $50^{\circ} \mathrm{C}$ for $10 \mathrm{~min}$. When added to deffated sunflower flour after $8 \mathrm{~h}$ of incubation, it hydrolyzed $92 \%$ of phytate (Agostini and Ida, 2006b). Thus, the objective of this work was to investigate the reduction of the PA content in two hybrid sunflowers by enhancing the phytase and acid phosphatase activities during natural germination.

\section{MATERIAL AND METHODS}

\section{Samples and germination}

Hybrid sunflower (Hilianthus annus) BRS191 and C11 seeds were kindly donated by Embrapa-Soja, Londrina, PR, Brazil. The seeds were previously sanitized by the method of Konietzny et al. (1995) and copiously washed with sterilized distilled water to remove the sanitizer residues of each hybrid. Thus 50 seeds were distributed on a paper sheet, wrapped, and placed in a germination chamber at $25^{\circ} \mathrm{C}$ under fluorescent illumination for 8 days. After 2, 4, 5, 6, and 8 days of germination, the new cotyledons were separated, freeze dried and triturated in mill in order to determine the amount of PA, soluble proteins, and phytase and acid phosphatase activities in triplicate.

\section{Quantification of PA}

The quantity of PA in $\mathrm{g}$ in $100 \mathrm{~g}$ of dry basis sample was determined by the Latta and Eskin (1980) technique with some modification by using Dowex-AGX-4 resin as in Ellis and Morris (1986).

\section{Determination of phytase and acid phosphatase activity}

Enzyme extraction and fractionation were carried out according to the Lolas and Markakis technique (1977). Essentially, enzyme was extracted from the sunflower meal homogenized in $2.0 \mathrm{~g} / 100$ of $\mathrm{CaCl}_{2}$ solution at $1: 10$ (w:v) for $1 \mathrm{~h}$ at $4^{\circ} \mathrm{C}$. To the filtered supernatant after centrifugation at 20,000x $\mathrm{g}$ ammonium sulphate was added up to $35 \mathrm{~g} / 100 \mathrm{~g}$ of saturation, followed by centrifugation. The ammonium sulphate was added to the filtered supernatant up to $80 \mathrm{~g} / 100 \mathrm{~g}$ of saturation. After centrifugation, the pellet was suspended in $5 \mathrm{~mL}$ tris-maleato $0.01 \mathrm{M}$ buffer $(\mathrm{pH} 6.5)$ dialyzed for 48 $\mathrm{h}$ with several buffer exchanges at $2^{\circ} \mathrm{C}$. Phytase and acid phosphatase activities were evaluated in this final extract.

Phytase activity was evaluated as described in Lolas and Markakis (1977) using sodium phytate as a substrate. Pi was determined by the ammonium molibdate method as described in Heinonen and Lahti (1981). One unit of phytase activity (1U PA) was defined as $\mu$ moles of $\mathrm{P}_{\mathrm{i}}$ liberated per minute. Acid phosphatase activity was measured by the release of $p$-nitrophenol from 
p-nitrophenylphosphate (Ullah and Gibson, 1988). One unit of acid phosphatase activity (1U APA) was defined as $\eta$ moles of $p$-nitrophenol released per minute.

\section{Protein quantification}

The amount of soluble protein was determined by the Lowry's method (1951).

\section{Statistical analysis}

PA content was submitted to variance analysis and Tukey test $(\mathrm{p}<0.05)$ under Statistical Analysis Systems (SAS, 1989).

\section{RESULTS AND DISCUSSION}

\section{Hybrid sunflower PA}

PA contents of the achenes of the two hybrids varied significantly $(\mathrm{p}<0.05)$ from 2.16 to $2.83 \mathrm{~g} / 100 \mathrm{~g}$ of sample probability as a consequences of seed variety and production area, since the soil phosphorus level could influence the PA content in the plants (Asada et al., 1969). The results were in accordance with Saeed and Cheryan (1988) that investigated the sunflower protein concentrates and isolates free of polyphenols and/or low phytate.

\section{PA and enzyme activity in germination}

The presence of PA and enzyme activities were observed particularly in cotyledons in germination under illumination at $25^{\circ} \mathrm{C}$ for 8 days, but absent in the axial parts of BRS 191 and C11 plantules. Figures 1 and 2 show the relationship between the PA content and phytase activity throughout the experiment. As can be seen, taking the first day of germination as control, on the $4^{\text {th }}$ day, the PA content decreased to 70.42 and $75.26 \%$ in BRS191 and $\mathrm{C} 11$, respectively, which was in agreement with Agostini and Ida (2006a) who observed the germination of hybrid sunflower M734, and previously reported by Egli et al. (2002) who investigated the germination of several grains and seeds. On the other hand, Coelho et al. (2008), from in vitro synthesis of phytate in culturing bean fruit explants concluded that different concentrations of phosphorus, sucrose, abscisic acid, glutamine and methionine caused an increase in the phytate of bean seed, showing that it could be possible to alter its content.

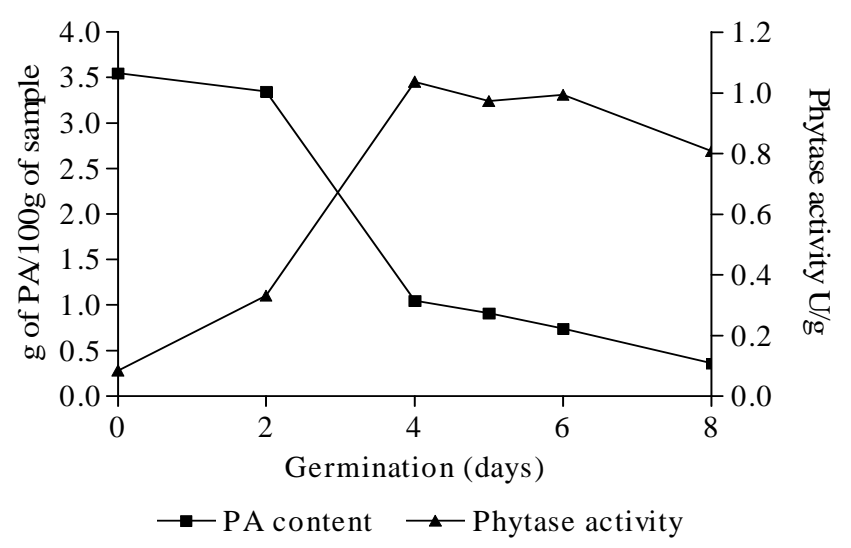

Figure 1 - Profile of PA content and phytase activity during germination of hybrid sunflower BRS191 for 8 days.

Phytases activities in non-germinated seeds varied from $0.08 \mathrm{UI} / \mathrm{g}$ for both BRS191 and C11, which demonstrated the correlation between the PA content and both enzyme activities. Thus, the common pattern was maximum phytase activity around the $4^{\text {th }}$ day of germination. In contrast, the lowest amount of PA was reached approximately on the same day of germination, indicating the hydrolysis of PA by this enzyme. 


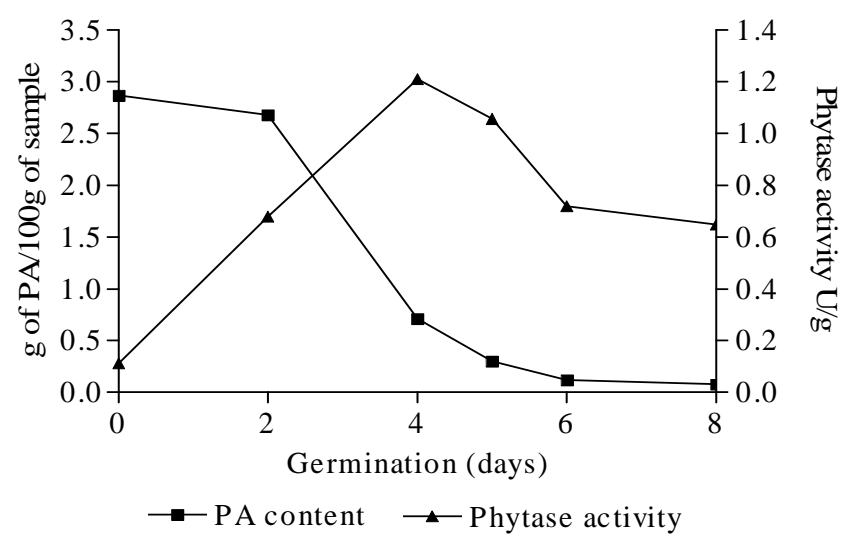

Figure 2 - Profile of PA content and phytase activity of hybrid sunflower C11during germination for 8 days.

Figures 1 and 2 show the existence of differences in details. The enzymatic activity was fairly constant in BRS191 from day 4 onwards, while it decreased fairly for C11 Agostini and Ida (2006a) found maximum phytase activity in hybrid sunflower $\mathrm{m} 734$ on the $4^{\text {th }}$ day of seed germination at $30^{\circ} \mathrm{C}$ which was of $1.06 \mathrm{U} / \mathrm{g}$ of sample reducing phytate content to $36.0 \%$ in relation to the starting sampling. Kanietzny et al. (1995) and Greiner et al. (2000) observed maximum phytase activity in espelt and barley on the $5^{\text {th }}$ and $4^{\text {th }}$ days of germination, respectively. Houde et al. (1990) observed that different varieties of canola germinated during 8 days presented phytase activity ranging from 0.69 to $1.75 \mathrm{IU} / \mathrm{g}$. Similar results were found by other workers in several germinated seeds (Eskin and Morris, 1986; Bartinik and Szafranska, 1987; Lu et al., 1987). Germination enhanced the phytase activity in all the legumes and oil seeds tested by Egli et al. (2002). During the first $24 \mathrm{~h}$, the activity remained stable, followed by an increase after $48 \mathrm{~h}$ and $72 \mathrm{~h}$. However, the underlying biochemical mechanism of this maximum phytase activity during the seed germination remained to be elucidated (Greiner et al., 2000).

All the hybrids presented an acid phosphatase activity pattern similar to that shown in Figure 3.

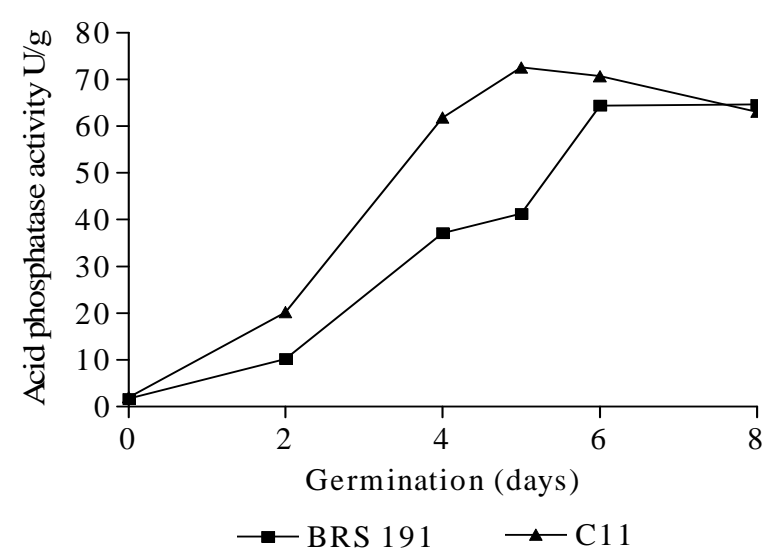

Figure 3 - Acid phosphatase activity of hybrid sunflowers during germination for 8 days.

C11 presented maximum activity of $72.59 \mathrm{UI} / \mathrm{g}$ of sample on the $5^{\text {th }}$ day of germination, while for BRS191, the maximum activity was $64.63 \mathrm{UI} / \mathrm{g}$ of sample on the $6^{\text {th }}$ of germination. According to
Agostini and Ida, (2006a) M734 presented maximum activity of $75.13 \mathrm{UI} / \mathrm{g}$ of sample and germination similar to that of $\mathrm{C} 11$. The maximum increase in the phosphatase activity was 30-40- 
fold higher than in non-germinated seeds. Silva and Trugo (1996) observed that maximum activity on the 8th day of germination in plants like lupine was 45 -fold higher than in non-germinating seeds. In contrast, acid phosphatase activity was about 50-fold higher than that of phytases, and Greiner et al. (2000) reported acid phosphatase activity 10fold higher than those of phytases in germinated barley. Lolas and Markakis (1977) reported that phytase and phosphatase hydrolyzed PA and other phosphorylated esters, indicating that phytates were not the only source of Pi under the activity of these two enzymes. The results of this experiment indicated that endogenous phytase partially acted upon PA, giving rise to the liberation of phosphorus and other minerals necessary for sunflower seed germination.

\section{CONCLUSIONS}

The germination of hybrid sunflowers is a natural biological process in which the decrease in phytic acid content by the enhancement of endogenous phytase and acid phosphatase activities. The highest enzymatic activities were at the $4^{\text {th }}$ and $5^{\text {th }}$ days of germination.

\section{ACKNOWLEDGMENTS}

The authors are grateful to Embrapa-SojaLondrina-PR/Brazil for the kind donation of sunflower seeds. JSA and RBN were under postgraduate scholarships from Conselho Nacional de Desenvolvimento Científico e Tecnológico-CNPq. EII is a CNPq Research Fellow. This project was partially financed by CNPq.

\section{RESUMO}

O objetivo deste trabalho foi investigar a germinação de girassóis híbridos BRS 191 e C11 com finalidade de reduzir o teor de AF e aumentar as atividades de phytases e fosfatases endógenas. A concentração do AF nos aquênios de girassóis híbridos variou de 2,16 a 2,83 g / $100 \mathrm{~g}$ de amostra $(\mathrm{p}<0,005)$. As atividades de fitases e fosfatases de girassóis BRS191 e $\mathrm{C} 11$ foram elevadas no $4^{\circ}$ e $5^{\circ}$ dia de germinação, respectivamente, com liberação do fósforo necessário para o desenvolvimento da semente. Estes resultados indicam que o AF do girassol hibrido reduz e a atividade de phytase aumenta em períodos distintos da germinação, possibilitando assim a aplicação desta enzima no controle do teor de AF em cereais, melhorando o seu valor nutricional.

\section{REFERENCES}

Agostini, J. S. and Ida, E.I. (2006a), Efeito das condições de germinação na redução do teor de fitato e ativação de fitase e fosfatase ácida. Semina: Ciências Agrárias, 27, 61-70.

Agostini, J. S. and Ida, E.I. (2006b), Caracterização parcial e utilização da fitase extraída de sementes germinadas de girassol. Pesquisa Agropecuária Brasileira, 41, 1041-1047.

Asada, K.; Tanaka, K. and Kasai, Z. (1969), Formation of phytic acid in cereal grains. Annual N. Y.Academy Science, 165, 801-814.

Association of Official Analytical Chemists (AOAC).(1995), Official Methods of Analysis of AOAC International, $16^{\text {th }}$ ed. $2 \mathrm{v}$. Arlington.

Bartnik, M. and Szafranskaa, I. (1987), Changes in phytate content and phytase activity during the germination of some cereals. Journal of Cereal Science, 5, 23-28.

Cheryan, M. (1980), Phytic acid interactions in food systems. CRC Critical Review Food Science and Nutrition, 13,297-335.

Coelho, M.M.C.; Bellato, C.M., Garcia, A.K.M.; Vitorello, V. A. and Azevedo, R.A.(2008), Variation in phytate accumulation in common bean (Phaseolus vulgaris L.) fruit explants. Brazilian Archives of Biology and Technology, 51(1), 163-173.

Dreher, M. L.; Roath, W. W.; Holm, E. T. and D'Appolonia, B. (1983), Yield, characteristics and composition of oil-type hybrid sunflower seed grown in North Dakota. Journal of the American Oil Chemists' Society, 60(11), 1876-1877.

Ellis, R. and Morris, R. (1986), Appropriate resin selection for rapid phytate analysis by ion-exchange chromatography. Cereal Chemistry, 63(1), 58-59.

Eskin, N. A. M. and Wiebe, S. (1983), Changes in phytase activity and phytate during germination of two fababean cultivars. Journal of Food Science, 48,270-271.

Egli, I.; Davidsson, L.; Juillerat, M.A.; Barclay, D. and Hurrell, R. F. (2002), The influence of soaking and germination on the phytase activity and phytic acid content of grains and seeds potencially useful for complementary feeding.Journal of Food Science, 67 (9), 3484-3488. 
Gibson, D. M. and Ullah, A. H. J. (1988), Purification and characterization of phytase from cotyledons of germinating soybean seeds. Archives of Biochemistry and Biophysics, 260(3), 503-513.

Graf, E. and Eaton, J. W. (1990), Antioxidant functions of phytic acid. Free Radical Biology and Medicine, $\mathbf{8}$, 61-19.

Greiner, R.; Konietzny, U. and Jany, K. D. (1998), Purification and properties of a phytase from rye Journal of Food Biochemistry, 22, 143-161.

Greiner, R.; Jany, K. D. and Alminger, M. L. (2000), Identification and properties of myo-inositol hexakisphosphate phosphohydrolases (phytases) from barley (Hordeum vulgare). Journal of Cereal Science, 31, 127-139.

Harbach, A. P. V. R. Z.; Costa, M. C. R.; Soares, A. L.; Bridi, A. M.; Shimokomaki, M.; Silva, C. A. da and Ida, E. I. (2007), Dietary corn germ containing phytic acid prevents pork meat lipid oxidation while maintaining normal animal growth performance. Food Chemistry, 100, 1630-1633.

Harland, B. F. and Oberleas, D. (1987), Anionexchange method for determination of phytate in foods: collaborative study. Journal Association Official Analytical Chemical, 6(4), 667-670.

Houde, R. L.; Alli, I. and Kermasha, S. (1990), Purification and characterization of canola seed (Brassica sp.) phytase. Journal of Food Biochemistry, 14, 331-351.

Konietzny, U.; Greiner, R. and Jany, K. D. (1995), Purification and characterization of phytase from spelt. Journal of Food Biochemistry, 18, 165-183.

Latta, M. and Eskin, M. (1980), A simple and rapid colorimetric method for phytate determination. Journal of Agricultural and Food Chemistry, 28(6), 1313-1315.

Lolas, G. M. and Markakis, P. (1977), The phytase of navy beans. (Phaseolus vulgaris). Journal of Food Science, 42, 1094-1106.

Lopes, H. W.; Leenhardt, F.; Coudray, C. and Kemesy, C. (2002), Minerals and phytic acid interactions : is it a real problem for human nutrition? International Journal of Food Science and Technology, 37, 727739.

Lowry, O. H.; Rosebrough, N. G.; Farr, A. L. and Randall, R. J. (1951), Protein measurement with the folin-phenol reagent. Journal of Biological Chemistry, 193, 265-275.

Lu, S.; Kim, H.; Eskin, N. A. M.; Latta, M. and Johnson, S. (1987), Changes in phytase activity and phytate during the germination of six canola cultivars. Journal of Food Science, 52(1), 173-175.

Maga, J. A. (1982), Phytate: Its chemistry, ocurrence, food interactions, nutritional significance, and methods of analysis. Journal of Agricultural and Food Chemistry, 30(1), 1-9.
Minihane, A. M. and Rimbach, G. (2002), Iron absorption and the iron binding and anti-oxidant properties of phytic acid. International Journal of Food Science and Tecnhnology, 37,741-748.

Oatway, L.; Vasanthan, T. and Helm, J. H. (2001), Phytic acid. Food Reviews International, 17(4), 419431.

Reddy, N. R.; Sathe, S. K. and Salunkhe, D. K. (1982), Phytates in legumes and cereals. Advances in Food Research, 28, 1-92.

Reyes, F. G. R.; Garibay, C. B.; Ungaro, C. B. and Toledo, M. C. F. (1985), Girassol: Cultura e aspectos químicos, nutricionais e tecnológicos. 88p, Fundação Cargil, Campinas, SP,Brasil.

Rossi, R. O. (1997). Girassol. 333p. Tecnoagro Ltda. Curitiba, Pr, Brasil.

Saeed, M. and Cheryan, M. (1988), Sunflower protein concentrates and isolates low in polyphenols and phytates. Journal of Food Science, 53(4), 1127-1131.

Sandberg, A. S. and Savanberg, U. (1991), Phytate hydrolysis by phytate in cereal: Effects on vitro estimation of iron availability. Journal of Food Science, 56 (5), 1330-1333.

Sandberg, A. S.; Hulthen, L. R. and Turk, M. (1996), Dietary Aspergillus niger phytase increases iron absorption in humans. Journal of Nutrition, 126, 476480.

Silva, L. G. and Trugo, L. C. (1996), Characterization of phytase activity in lupin seed. Journal of Food Biochemistry, 20, 329-340.

Simons, P. C. and Versteegh, H. A. J. (1990), Improvement of phosphorus availability by microbial phytase in broilers and pigs. British Journal of Nutrition, 64, 525-540.

Soares, A. L.; Olivo, R.; Shimokomaki, M. and Ida, E. I. (2004), Synergism between dietary vitamin E and exogenous phytic acid in prevention of warmed-overflavor development in chicken pectoralis major. Brazilian Archives and Biology and Technology, 47(1), 57-62.

Ullah, A. H. J. and Gibson, D. M. (1988), Purification and characterization of phosphatase from cotyledons of germinating soybean seeds. Archives of Biochemistry and Biophysics, 260(2), 514-520.

Wodzinski, R. J. and Ullah, A. H. J. (1996), Phytase. Advances in Applied Microbiology, 42, 263-302.

Zhou, J. R. and Erdman, Jr. J. W. (1995), Phytic acid in health and disease. Critical Reviews in Food Science and Nutrition, 35(6), 495-508.

Received: November 18, 2008; Revised: February 13, 2009; Accepted: October 21, 2009. 